\title{
猪苗代湖における内部静振観測 FIELD OBSERVATION OF INTERNAL SEICHE IN LAKE INAWASHIRO
}

\author{
戸塚 康則 ${ }^{1} \cdot$ 田中 $\quad$ 仁 $^{2} \cdot$ 藤田 豊 $^{3} \cdot$ 山路 $\quad$ 弘人 ${ }^{4}$ \\ 愛川 薫 $^{5} \cdot$ 多久和 学 $^{6} \cdot$ 沢本 正樹 $^{7}$ \\ Yasunori TOTSUKA, Hitoshi TANAKA, Yutaka FUJITA, Hiroto YAMAJI, \\ Kaoru AIKAWA, Manabu TAKUWA and Masaki SAWAMOTO \\ 1 学生会員 東北大学大学院工学研究科 土木工学専攻（T980-8579 宮城県仙台市青葉区荒巻青葉06） \\ 2 正会員 工博 東北大学教授 大学院工学研究科 土木工学専攻 \\ 3 正会員 工修 日本大学助教授 工学部 土木工学科 \\ （厂963-8642 福島県郡山市田村町徳定字中河原 1 番地） \\ 4 正会員 東北大学教務職員 大学院工学研究科 土木工学専攻 \\ 5 福島県 県中建設事務所（T963-8540 福島県郡山市簏山1-1-1） \\ 6 学生会員 東北大学工学部 土木工学科 \\ 7 フェロー 工博 東北大学教授 大学院工学研究科土木工学専攻
}

\begin{abstract}
Lake Inawashiro is a typical deep acid lake in Japan. The water from Nagase river is the cause of acid water in this lake. Deep lakes have a possibility of occuring internal seiche, which is very important in terms not only of hydraulics but also of water quality, because it is involved water purification and mixture.

A field observation was carried out in autumn season meanwhile the thermal structure was overturned. From the result of water temperature observation, internal seiche was successfully detected. The wave height and difference of water temperature variation reached to about $15 \mathrm{~m}$ and 8 degree, respectively and internal seiche continued about 6 days. After this event the thermocline was disappeared. It suggests that the internal seiche promoted lake water mixing in full depth scale.
\end{abstract}

Key Words : Lake Inawashiro, stratification, thermocline, internal seiche

\section{1. はじめに}

水深の深い湖沼では，春季から夏季にかけての気温上 昇に伴い水温躍層が形成され，霞浦に代表されるよう な浅い湖とは異なる流動を示す．特に秋季は, 成層の衰 退と季節風の影響により, 内部波の発生頻度が高まる. 内部波に関しては, 例えば村岡らが中禅寺湖での内部波 観測を行っている11)2３）．表層の混合層がある厚さ以 上に達すると強い風が長時間連風しても，ごく表層付近 の等温線が破壊されるにとどまり，風によるエネルギー の大部分は界面の傾きによるポテンシャルエネルギーに 変換されてしまう ${ }^{1)}$. 風外力による水温躍層の侵食効果 が小さいならば，水温躍層場に起因する内部波の役割が 重要な位置を占める22. しかし, 内部波はある程度は伝 播するが，部分的な領域に影響を及ぼす程度にすぎない．
これに比べて内部静振は，湖全域にわたる変動であり湖 内の水質を大きく変化させる効果を持つ. ゆえに, 内部 静振の諸特性・湖水に与える影響を解明することは非常 に重要である. 中禅寺湖においても内部静振の観測はな されている(3)が，まだ観測例が多いとは言えないのが現 状である.

日本でも有数の面積と水深を誇る湖として，猪苗代湖 が挙げられる. 水質的な調査は藤田ら ${ }^{4)}$ によってなされ ているが, 水理学的な钼測が具体的に行われた例は大正 時代にさかのぼる. 当時の資料 ${ }^{5)}$ には, 表面静振に関し ては周期 19 分・9分の 2 つの特徵的な振動が存在するこ と, さらに, 湖東における水深 $14 \mathrm{~m}$ 付近で一日の間に水 温が $10^{\circ} \mathrm{C}$ 以上も変化したことが記録されている. この水 温変動は内部静振の存在を示唆しており, それもかなり の規模であることが分かる. そこで本研究では，猪苗代 湖に注目し, 数点において多層にわたり水温計を設置し 
て内部静振の観測を試みた. 水温鈶直分布の変動から, 本湖における内部静振の特性と水温構造に与える影響を 明らかにする事を目的とする.

\section{2. 観測概要}

\section{（1） 観測地の概要}

福島県中央に位置する猪苗代湖（図-1）は日本で第四 の面積（105 $\mathrm{km}^{2} ）$ を誇り, 強酸性の水質を有する清澄な 湖として有名である. しかし近年, 湖北部地域の観光市 街化に伴い, 水質污濁の進行が問題となうている. 猪苗 代湖の水は福島県における重要な水源として多くの人に 利用されており，良好な水質の維持は必要不可欠なもの である. 本湖の水質を決定付ける主な要因として, 北部 観光市街地からの排水, 及び湖北東部から流入する強酸 性水質の長瀬川流入水の二つが考えられる. 長瀬川の上 流には沼尻温泉地帯の湧・排出地帯があり,これが酸性 水質の源である ${ }^{6)}$ ．流入水の大部分が長瀬川によるもの であり，滞留時間がおよそ5.4年である7)ことから，か なり閉鎖的な湖であると言えよう. 加えて, 最大水深が 94.6mに達するため, 夏季には顕著な水温躍層が形成さ れる.

\section{（2） 観測項目 \\ a） 鉛直水温分布時系列観測}

気温の低下により成層が弱まった湖内に強風が吹き付 けた場合, 内部静振の発生が予想される. 内部静振の振 動は長軸方向の動きが卓越するであろうと考え，1999年 は図-2（等深線は水深10mごと）に示すSt.1, St.2, St.3 の湖内 3 点に, 2000年6月は短軸方向St.4, St.5を含めた 5 点に自動記録式小型IC水温計MDS-T（アレック電子社 製）を設置したが，St.2，St.3が欠測となってしまった.

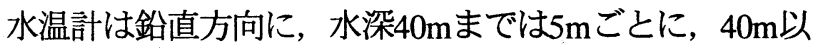
深は10mごとに設置した，測定時間間隔は10分である.

\section{b) 水位測定}

湖北部と南部に水位計を設置し, 水面変動の動きを捉 える. 水位計設置位置を図-2に示す．測定時間間隔は1 分とする.

\section{C） 風速測定}

長瀬川河口東部に風速計を設置し，10分ごとのデータ を採取する. 風速データは, 5秒ごとに測定した風速を 10分間移動平均した值として得られる.

\section{3. 観則結果と考察}

（1） 1999年10月の水位 - 水温時系列変化

はじめに述べた通り, 本湖には2つのモードの表面静 振が存在していることが分かっている. しかし, あまり

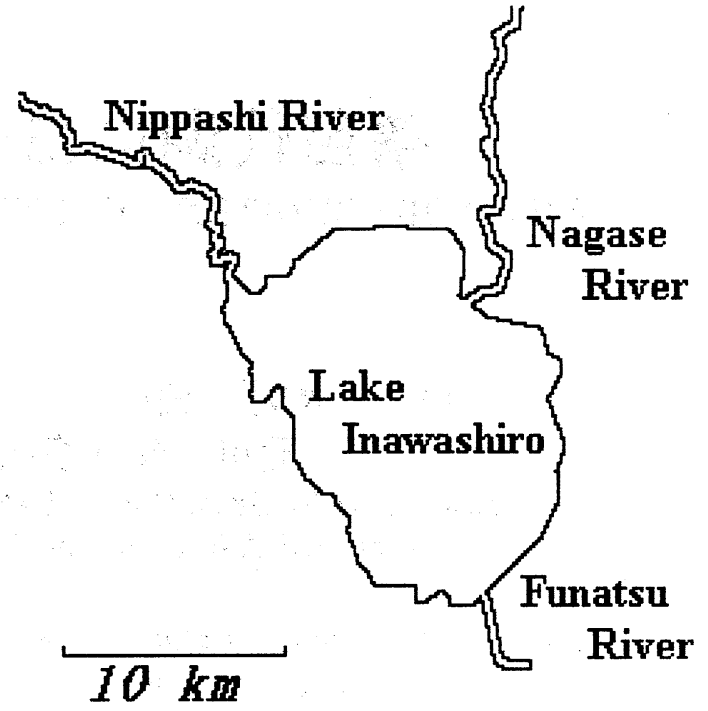

図-1 猪苗代湖全体図

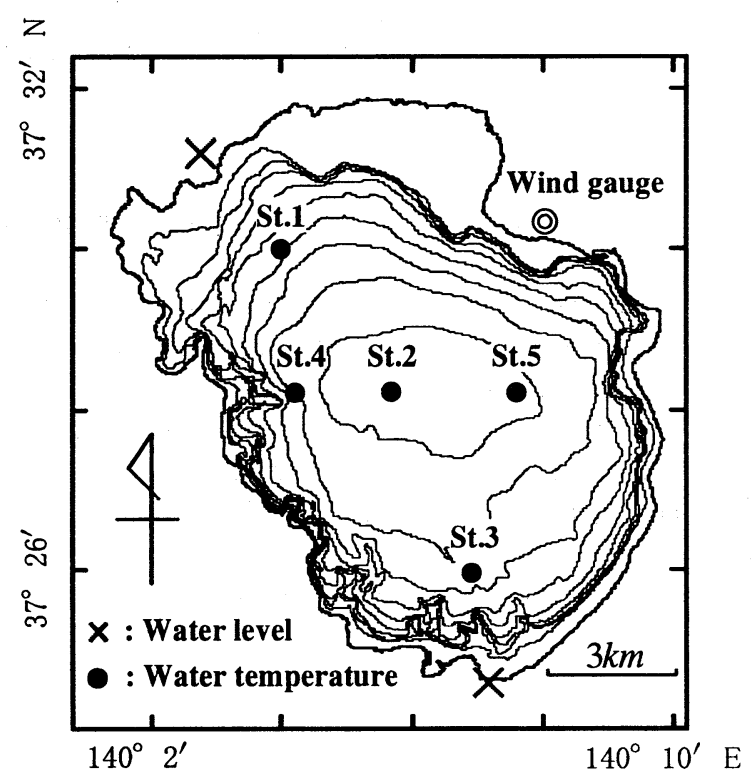

図-2 水温計・水位計設置位置

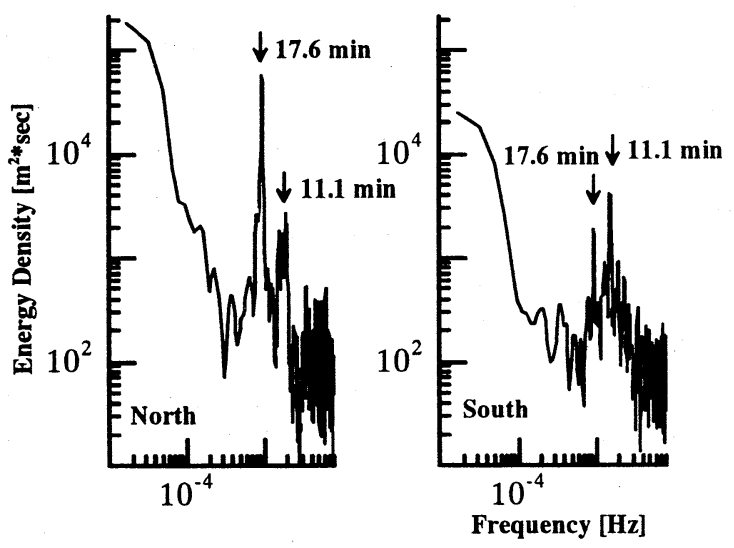

図-3 湖北・湖南水位スペクトル 

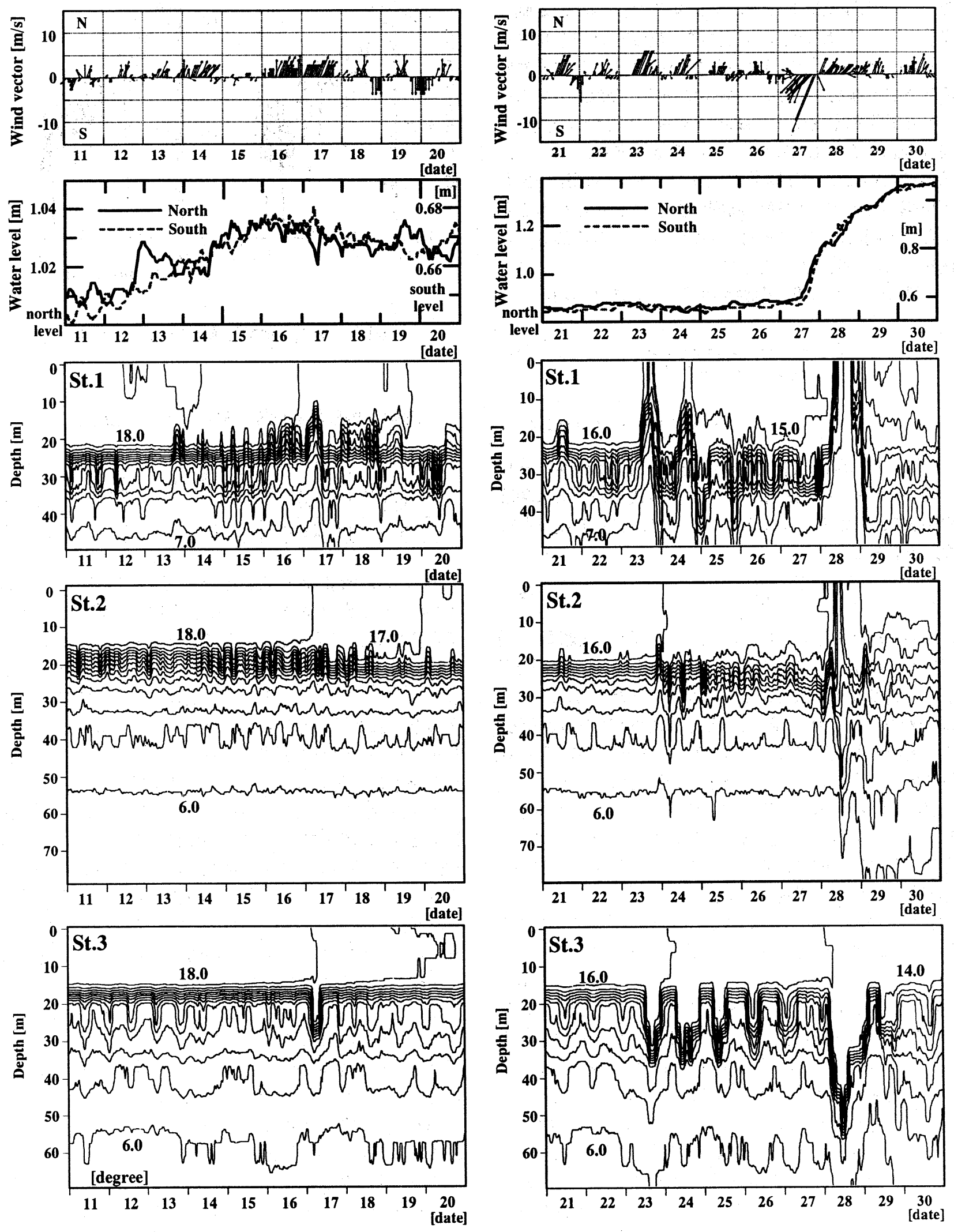

图-4 1999年10月, 風速·水位 - 水温

(湖北・湖心・湖南) 分布データ

図-5 1999年10月, 風速 - 水位 - 水温

（湖北・湖心・湖南）分布デー夕 
にも古い記録であるため計測精度が不明である．そこ で, 水位測定間隔を1分とし，この表面静振の抽出を試 みた. 内部静振に関しては後述するが，界面の変動は 多少なりとも水面変動へと影響を及ぼす事が予想され るため, 界面の動きが見られない10月22日の水位変動 のスペクトルを計算した. 図-3に湖北・湖南水位のスペ クトル計算結果を示す. 湖北・湖南ともに17.6分周期の 表面静振が存在していることが確認できる. しかし, 湖南においては17分周期の振動よりも11分周期の振動 が卓越しており，同様の周期が湖北にもみられること から, 本湖には17.6分・11分周期の 2 つの表面静振が存 在することが明らかとなった.

等深長方形湖の静振理論解は式（1）で表される.

$$
\begin{gathered}
T=\frac{2}{c \sqrt{m^{2} / a^{2}+n^{2} / b^{2}}} \\
(m=0,1,2 \cdots \quad n=0,1,2 \cdots)
\end{gathered}
$$

ここに, $\mathrm{T}$ : 周期[sec], $\mathrm{c}$ : 波速 $[\mathrm{m} / \mathrm{s}], \mathrm{m}, \mathrm{n}$ : 振動モード, $\mathrm{a}, \mathrm{b}:$ 湖の長さ・幅員 $[\mathrm{m}]$ である. 猪苗代湖の平均水深は 約60mであるので, $\mathrm{h}=60$ として式（2）より波速を求め, 周期を計算した.

$$
c=\sqrt{g h}
$$

$\mathrm{a}=13000[\mathrm{~m}]$ （長軸方向）, $\mathrm{m}=1, \mathrm{n}=0$ の時, 周期は17.8分 であることから, 観測で得られた17.6分周期の静振は基 本モードの表面静振であるといえる. また, $\mathrm{m}=1, \mathrm{n}=1$, $\mathrm{b}=11000[\mathrm{~m}]$ （短軸方向）とすると, 周期が11.5分となり, 11分周期の振動はは長・短軸方向基本モ一ドの表面静振 が重複した重複波モードであると考えられる.

図-4に1999年10月11日〜20日の風速・水位・水温分布 データを，図-5に10月21日〜30日の同データを示す．風 速デー夕はこの期間欠測であったため, 猪苗代湖北部に 位置するアメダス観測所にて得られたデータを使用する. 今回は, 内部静振に対応した数時間オーダーの水位変化 を見るため1時間移動平均した水位を図示した.

10 月中旬は明確な水温躍層が存在している．湖北

（St.1）の水温時系列変化を見ると, 定期的な界面変動 を示しているが，湖南（St.3）ではほとんど变化が見ら れない. ゆえに, この動きは湖長軸方向の内部静振では ない. 北部の湖棚で発生した擾乱が内部波となってSt.1 へと到達した様子を捉えたものであると予想される.

16・17日にはまとまった南風が吹いており, 湖南

（St.3）でも一度大きな界面変動が発生したが，持続的 なものではなく，すぐに安定した状態へと移行している. 内部静振が発生するにはまだ成層が強いようである.

10月21日〜30日にかけての水温分布によると, 湖内の 界面には大きな変化が見られる. 10月中旬の変動とは異 なり, 北部の界面と南部の界面とが逆位相で変位してい る様子がわかる. 逆に, 湖心（St.2）での水温は湖北・
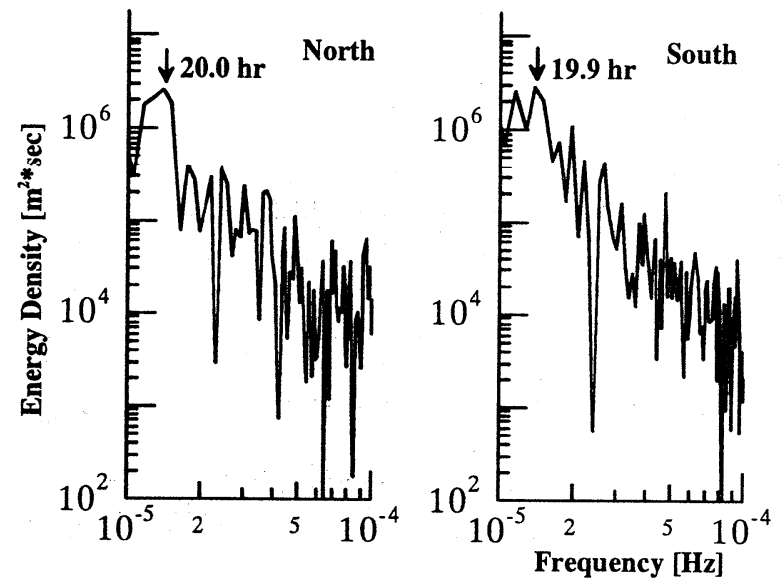

図-6 湖北・湖南界面変位スペクトル

表-1 内部静振周期計算パラメータ及び結果

\begin{tabular}{|c|c|c|c|c|}
\hline & $\varepsilon$ & $\mathrm{h}_{1}[\mathrm{~m}]$ & $\mathrm{h}_{2}[\mathrm{~m}]$ & $\mathrm{T}[\mathrm{hr}]$ \\
\hline St.1 & 0.000842 & 22 & 43 & 20.8 \\
\hline St.3 & 0.000847 & 18 & 52 & 21.6 \\
\hline
\end{tabular}

湖南の水温変動に比べるとほとんど変化していない，以 上3点の水温変動結果より, 湖心を振幅の腹とした大規 模な内部静振が発生していたことが予想される.この時 期は躍層上の水温が徐々に低下して, 成層が次第に弱 まっている. そこにまとまった風が吹き付けたためこの ような内部静振が発生したと考えられる. 特に, $27 \cdot 28$ 日東北地方は台風の影響で大荒れの天気であり，27日深 夜の風速は $14 \mathrm{~m} / \mathrm{s}$ に達する. 水位は28日から30日にかけ て20cmも上昇しており, 河川からの流入水, 及び降雨 による湖水量の増加はかなりの量に達する. 湖面面積は $105 \mathrm{~km}^{2}$ であるので, 湖水増加量はおよそ $2.1 \times 10^{7}$ ton と算 定される. 23日に発生した内部静振に台風によるさまざ まな条件が奇与し， 28 日に湖北では水深 $40 \mathrm{~m}$ の低層水が 水面にまで湧昇している. 水温変化が約 $8^{\circ} \mathrm{C} に も$ 達する 大規模な内部静振であった.

この10月末に発生した内部静振後は水温の等温線間隔 が大きく広がりつつある. つまり,この内部静振によつ て湖内の鈶直循環が促進されたわけである. 28日に発生 した内部静振は降雨や流入水などの影響を受けているた め偶発的な現象であろう. しかし，23日から27日の内部 静振は成層の衰退と季節風によって引き起こされたもの であり, 例年降温期に発生していると思われる. ここで, 温度勾配がもっとも大きな $13^{\circ} \mathrm{C}$ 等温線を界面の動きと みなしてスペクトルをとり周期を計算した. 結果を図-6 に示す. 湖北と湖南での周期を平均すると， 20.0 時間と なった. 表面静振と同様に, 理論解との比較をしてみる. 式（1）における, 波速 c を式（3）に置き換えると 内部静振の振動周期を表す式となる. 

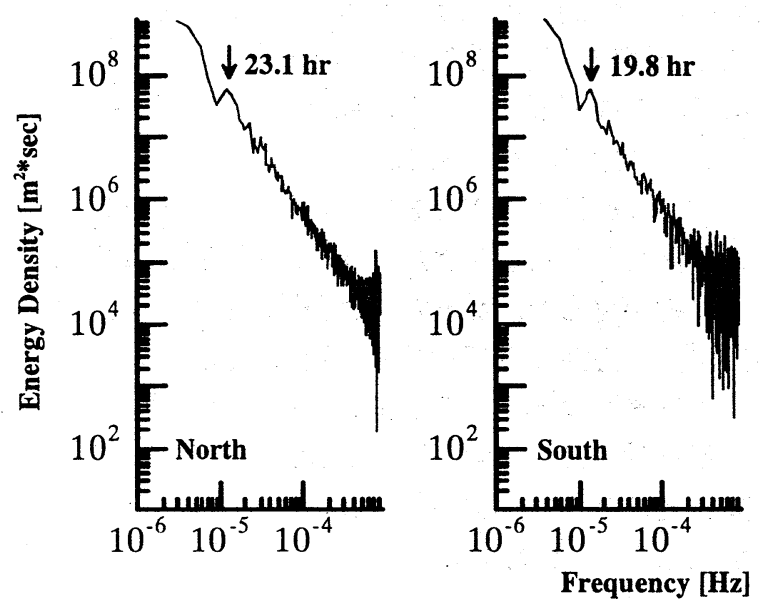

図-7 内部静振発生時における水面変動スペクトル

$$
c_{i}=\sqrt{\frac{\varepsilon g h_{1} h_{2}}{h_{1}+h_{2}}}
$$

ここに, $\varepsilon$ : 水温2首系の相対密度, $\mathrm{h}_{1}, \mathrm{~h}_{2}$ : それぞれ 躍層から水面までの深さ [m], 躍層から湖底までの深さ [m]である. 各パラメーター及び計算結果は表-1の通り である. 湖北と湖南の周期を平均すると， 21.2 時間と なった. 実測から得られた周期と理論解から計算された 周期はほぼ一致している. この界面変動が単に風の吹き 寄せ現象であった場合, 界面の変動周期が風の変動周期 に対応するはずである. 図-5の風速べクトル図より, 風 はほぼ24時間周期の変動を示しており, 界面変動周期と は対応していない. さらに, 風応力と界面傾斜の関係を Kajiura ${ }^{8)}$ に倣って計算したところ, 観測期間に吹いてい た $5 \mathrm{~m} / \mathrm{s}$ の風に対する界面傾斜は約 $1.5 \mathrm{~m}$ に過ぎない. ゆえ に, これらの界面変動は, 吹き寄せではなく内部静振に よるものであると結論付けられる.

内部静振が発生している期間（21日から27日）におけ る水位の変動に関してスペクトルを計算した結果が図-7 である. 卓越する周期として, 湖北・湖南それぞれ 23.1 時間・19.8時間の振動が発生していることが分かる. 湖 北での水面変動周期は内部静振のそれよりも大きな值と なったが, これは本湖北部に広がる浅瀬の影響により局 所的に振動モードが变化したためであると思われる. 以 上の結果から, 内部静振が発生している期間には微小で はあるがそれと同程度の卓越周期が水面変動にも現れる

\section{ことが確認された.}

界面は約5時間（1/4周期）で $15 \mathrm{~m}$ 前後変位する事から， 鈶直方向の流速は概算で $8.3 \times 10^{-4} \mathrm{~m} / \mathrm{s}$ と算定される. 非 常にゆっくりとした動きではあるが, 湖水混合の観点か らすると, 十数 $m$ もの鉛直変動を引き起こす内部静振は, 猪苗代湖のように水深の深い湖において, 吹送流による 混合に比べて非常に効果的である.

\section{（2） 2000 年6月の水位 · 水温時系列変化}

図-8に2000年6月 21 日 30日の風速・水位・水温分布
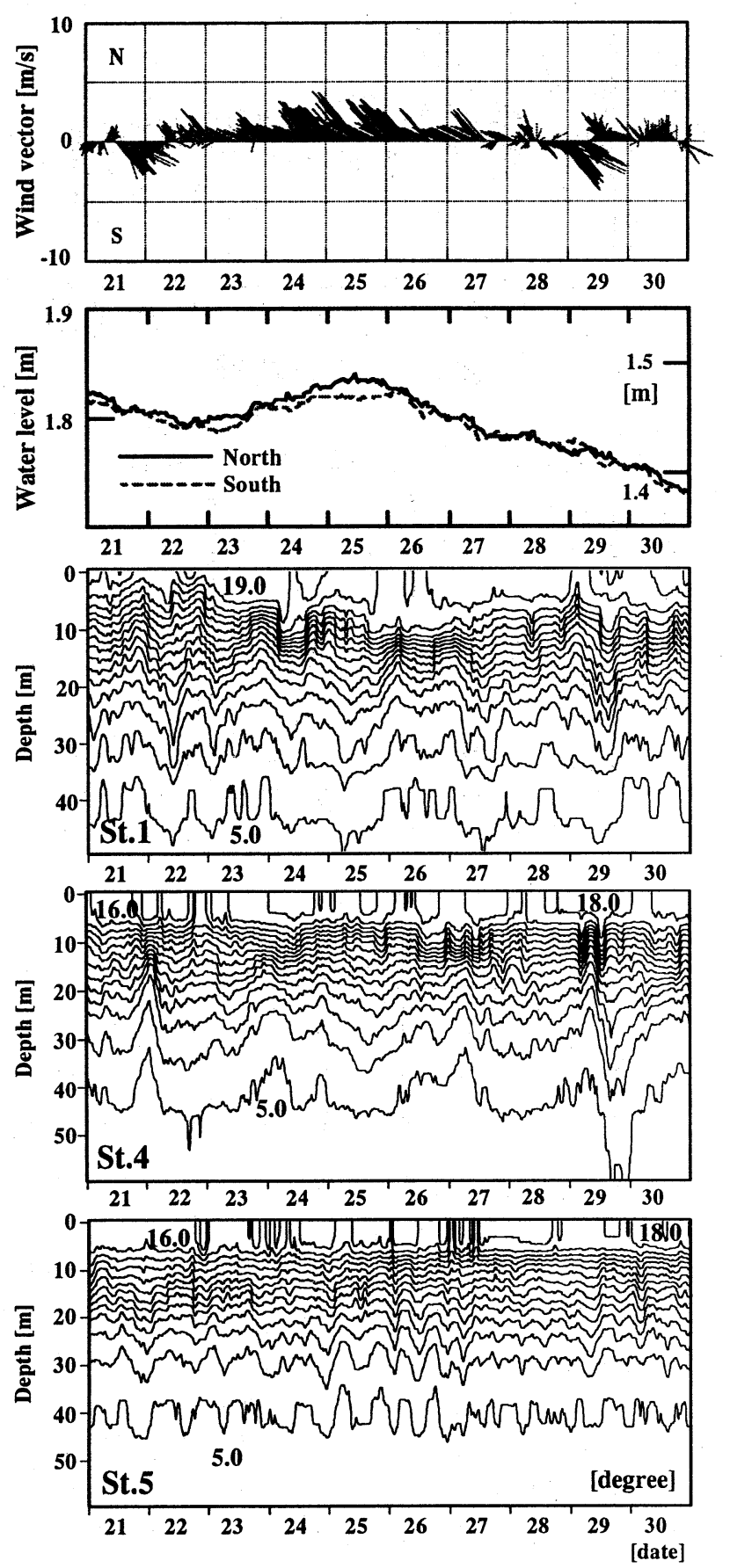

网-8 2000年6月，風速・水位・水温 (湖北 - 湖西

・湖東) 分布デー夕

（湖北・湖西・湖東）デー夕を示す. 風速デー夕は現地 観測により得られたものである. まだ明確な水温躍層は 存在していないが, 水面付近はかなり温度が上昇してお り, 強成層期へと遷移している. 昨年10月の内部静振に 比べるとかなり小規模ではあるが, 短軸方向（東西方 向）に周期的振動が発生している. 過密等温層の中間值 である $12^{\circ} \mathrm{C}$ 界面の動きとみなし，図-9にSt.4，5におけ る $12^{\circ} \mathrm{C}$ 等温線経時変化を示す. 湖東と湖西の等温線が逆 位相で変動しており, 界面全体にわたる振動であること がわかる. 図-10は $12^{\circ} \mathrm{C}$ 等温線の変動スペクトル図であ る. 3 地点に共通した卓越周期として24.3時間が挙げら 


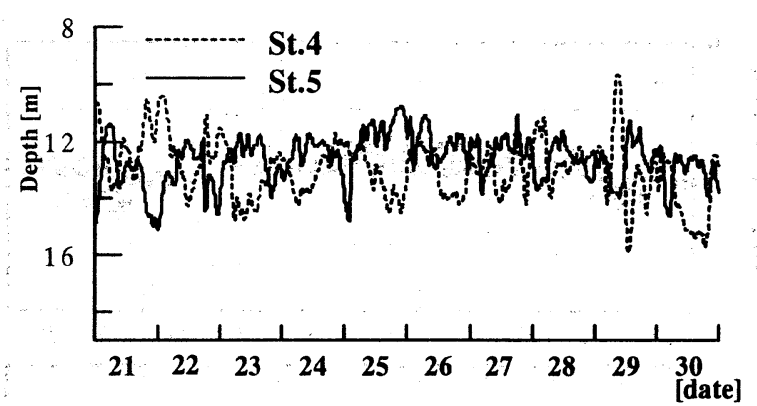

図-9 $12^{\circ} \mathrm{C}$ 等温線変動

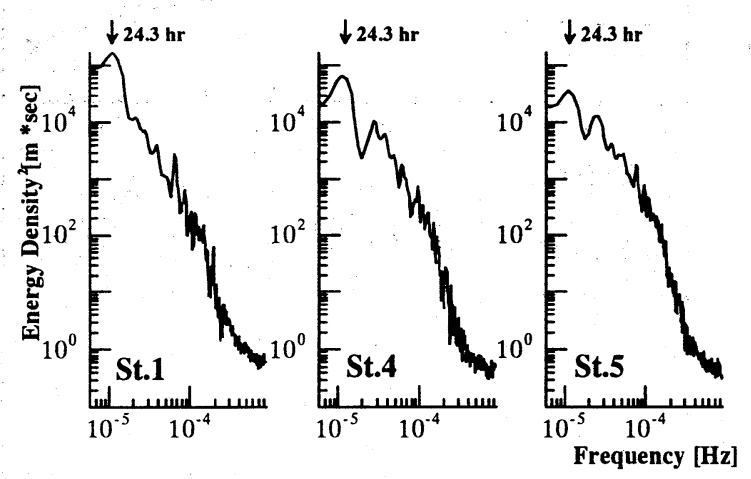

図-10 $122^{\circ} \mathrm{C}$ 等温線スペクトル

表-2 内部静振周期理論解

\begin{tabular}{|c|c|c|c|c|}
\hline & $\varepsilon$ & $\mathrm{h}_{1}[\mathrm{~m}]$ & $\mathrm{h}_{2}[\mathrm{~m}]$ & $\mathrm{T}[\mathrm{hr}]$ \\
\hline \hline St.1 & 0.00106 & 15 & 50 & 20.9 \\
\hline St.4,5 & 0.00106 & 15 & 70 & 17.0 \\
\hline
\end{tabular}

れる. 表-2に理論周期の計算結果を示す．表中のSt.1は 長軸方向, St.4,5は短軸方向に対応した理論解を算出し た結果である. 長軸方向・短軸方向ともに, 観測の結果 得られた周期に相当する振動ではない. ゆえに，この24 時間周期の振動は単一方向の内部静振であるとは考えら れない. そこで, 内部ケルビン波の回転モードについて 検討してみる. 式（3）から, 界面の伝播速度を求める. 水温躍層が明確でないため, 上下層水温を决定するのは 困難であるが，平均的な值として $\mathrm{h}_{1}=15[\mathrm{~m}], \mathrm{h}_{2}=45[\mathrm{~m}], \varepsilon$ $=0.00106$ を用いて波速を求めると $\mathrm{c}=0.342[\mathrm{~m} / \mathrm{s}]$ と算出さ れる. 北部の浅瀬を考慮して, 本湖を半径 $5 \mathrm{~km}$ の円形湖 と仮定し，水平方向の回転周期を求めると 25.5 時間とな り, 図-10に示される卓越周期に相当する值となつた.

今回得られたデー夕からは, 具体的な回転の様子や回 転方向を捉える事はできなかつたが，これらの結果は， 猪苗代湖程度の面積を有する湖にも, 回転性の内部ケル ビン波の動きが見られるという可能性を示唆したもので ある.

\section{4. おわりに}

本研究では, 福島県猪苗代湖を対象として成層の弱い
時期に水温変動の現地観測を行い，成層の衰退と強い季 節風の影響により, 長軸方向の大規模な内部静振が発生 することを確認した. この内部静振後には水温躍層が破 壊され，全層にわたる湖水混合が促進された。このよう に, 内部静振による水温躍層への影響を具体的なデ一夕 として捉えることができた. また, 受熱期においても界 面の変動が見られ，数mの内部静振が発生した．本湖の 静振は長軸方向のみではなく, 短軸方向にも振動してお り,より複雑なモードで変動していると考えられる. ま た, 受熱期に湖内3点における水温変動のスペクトルを 計算した結果, 内部ケルビン波の回転周期に相当する周 期が抽出され，回転性の動きが存在する可能性が示され た.

今回の観測により得られた大規模内部静振は, 平常時 の気象条件によって発生したため, 毎年この時期に発生 する可能性があると考えられる. 今後も継続的に観測を 続け，発生条件や湖水に対する影響をさらに詳細に検討 し,さらに, 今回は欠測のため不可能であった内部静振 時の三次元的な構造を捉える必要がある.

謝辞 : 本研究を行うにあたり御協力頂いた福島県県中建 設工事事務所, 福島県猪苗代土木事務所, 福島県喜多方 建設工事事務所, マリーナ・レイク猪苗代(株) 翁島港 マリーナに深謝する.

\section{参考文献}

1) 村岡 浩爾, 平田 健正: 中禅寺湖の内部波, 第27回 水理講演会論文集, pp. 179-184, 1983.

2) 村岡 浩爾, 平田 健正: 中禅寺湖の内部波 (2), 第 28回水理講演会論文集, pp. 327-332, 1984.

3) 平田 健正, 村岡 浩爾: 中禅寺湖の岸付近における 水温変動特性, 第29回水理講演会論文集, pp. 377-382, 1985.

4)藤田 豊, 田中 仁, 坂本 優, 志田 敬, 武田 忠 良, 田坂 嘉識, 渡辺 寿之, 渡辺 善朗: 猪苗代湖 の長軸方向3水域における水質観測, 土木学会東北支 部技術研究発表会, pp. 276-277, 2000.

5) 東北帝国大学理科報告, 仙台出版, 第 1 巻, 第5号, 1913.

6) 小野寺 英也 : 猪苗代湖の酸性化と生息魚類について, 学報, 野口英世記念会, 第2巻 第1号, pp. 2-8, 1980.

7) 千葉 茂: 猪苗代湖の水質, 学報, 野口英世記念会, 第6巻. 第1号, pp. 7-9, 1984.

8) Kajiura, $K$ : The effect of winds on the stratified lake water, Journal of Oceanographical Society of Japan, Vol.8, No.2, pp.67-71, 1952. 